\title{
Conflict, Terrorism and the Media in Asia
}

Rebekah L. Bina

Shulman, Rogers, Gandal, Pordy \& Ecker

Follow this and additional works at: https://www.repository.law.indiana.edu/fclj

Part of the Communications Law Commons, and the Comparative and Foreign Law Commons

\section{Recommended Citation}

Bina, Rebekah L. (2007) "Conflict, Terrorism and the Media in Asia," Federal Communications Law Journal: Vol. 59 : Iss. 2 , Article 8.

Available at: https://www.repository.law.indiana.edu/fclj/vol59/iss2/8

This Book Review is brought to you for free and open access by the Law School Journals at Digital Repository @ Maurer Law. It has been accepted for inclusion in Federal Communications Law Journal by an authorized editor of Digital Repository @ Maurer Law. For more information, please contact rvaughan@indiana.edu.

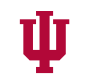

JEROME HALL LAW LIBRARY INDIANA UNIVERSITY Maurer School of Law
Blooming ton 


\title{
Conflict, Terrorism and the Media in Asia
}

\author{
Rebekah L. Bina*
}

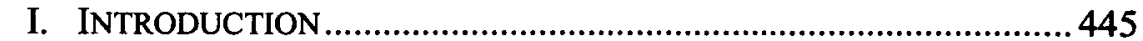

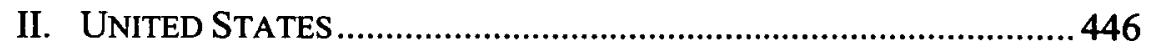

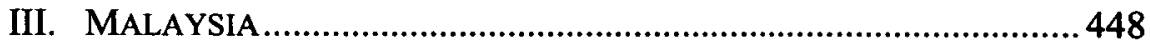

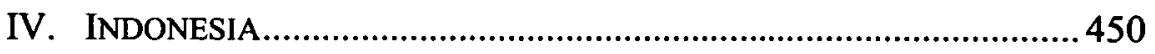

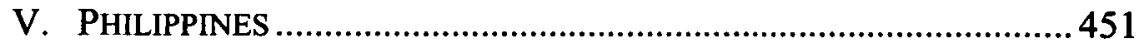

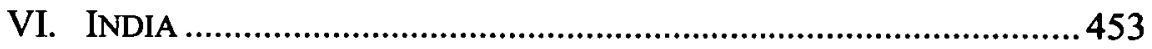

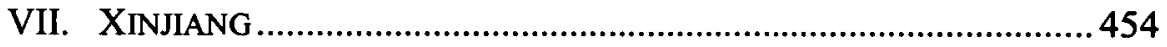

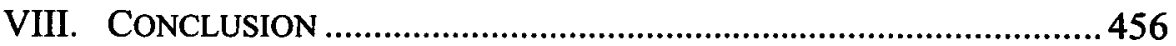

\section{INTRODUCTION}

Conflict, Terrorism and the Media in Asia ${ }^{1}$ is the fourth and latest release in a series of publications by a group of diverse scholars focused on studying the impact of media and changes in societal culture in Asia. ${ }^{2}$ Previous books in the series have dealt with analyzing the television industry, ${ }^{3}$ journalism and democracy, ${ }^{4}$ and film and copyright ${ }^{5}$ issues across Asia. This fourth book provides a study of the subnational conflicts across Asia and how they fit into the global "War on Terror." The authors do this by examining the condition of free press, access to media, and

* Rebekah L. Bina currently practices law as an associate attorney in the Corporate Telecommunications group of Shulman, Rogers, Gandal, Pordy \& Ecker in Rockville, Maryland. She earned her Master's Degree in Media Management and her J.D. with a certificate in National Security Law from Syracuse University.

1. Conflict, Terrorism and tHE Media IN Asia (Benjamin Cole ed., RoutledgeCurzon 2006) [hereinafter Cole].

2. Routledge Media, Culture and Social Change in Asia has an editorial board comprised of university scholars from Australia, England, India, and the United States.

3. Television across Asia, TV Industries, Programme Formats and GLOBALISATION (Albert Moran \& Michael Keane eds., RoutledgeCurzon 2003).

4. JOURNALISM AND DEMOCRACY IN ASIA (Angela Romano \& Michael Bromley eds., RoutledgeCurzon 2005).

5. Laikwan Pang, Cultural Control and Globalization in Asia (2005). 
diversity in news reporting. They explore how media can be a tool in facilitating ideological coalition, but also how access to and power over the media are used in an attempt to shelter populations and maintain political stability.

The book begins with an introductory commentary on journalism in the United States. The remaining chapters deal with the role of media in the current political struggles, conflict, and terrorist activities in five Asian regions: Malaysia, Indonesia, Philippines, India, and China. Each chapter is written by an author familiar with that region's media outlets and political environment, pre- and post-September 11, 2001.

The book provides significant background, factual information, and analysis of each region's conflicts. However, the chapter materials also draw heavily on the personal opinions, experiences, education, and studies of each author. The chapters are revealing but brief, and only provide a glimpse into the complex issues these regions and this part of the world face. Terrorism is by no means a new concept, yet its definition remains vague and inexact as regions of the world encounter different types of terrorism and deal with it in their own way. This book attempts to illustrate that this is true even when the terrorist activities are based in similar or shared ideology.

It is important to note that while it would be a monumental task to incorporate all facts and history of the complex conflicts facing this region, some chapters provide a more objective perspective than others. By design, this book is meant to question the tactics and politics of the regions, but at times the reader is left wondering whether counterpoints were missed or otherwise avoided. Certainly an interesting and valuable reference, this book is better considered summary commentary rather than a thorough impartial analysis. The remainder of this Review will provide a brief summary of the conflicts, types of terrorism, and media involvement this book reveals.

\section{UNITED STATES ${ }^{6}$}

Probably the least objective of all the chapters, this chapter analyzes the methods and influence of the United States media. Specifically, the author deals with the journalistic style of network and cable television news reporting of the "War on Terrorism," pointing out its failures and the effect on both American and foreign perceptions of U.S. government policy. He stresses the importance of the American media's responsibility to operate

6. This chapter is written by Toby Miller, a professor of English, Sociology, and Women's studies at the University of California Riverside and a published author on culture and media. See University of California Faculty Directory (2006), available at http://www. facultydirectory.ucr.edu. 
as a democratic "checking" function on the government, but he argues media consolidation, the influence of Republican-backed think tanks in Washington, and the financial support of high-profile Republicans forced nationalistic reporting that gave media consumers an unrealistic sense of both the cultural and military situation in the events following September $11,2001 .^{7}$ By now this is not a wholly unique argument. However, the author points to several incidents following the invasion of Afghanistan as evidence of his claims, including: MSNBC's firing of Phil Donahue, ${ }^{8}$ Condoleezza Rice's request for news organizations to cease airing tapes of Osama bin Laden containing coded messages, ${ }^{9}$ the Pentagon's purchase of the rights to satellite photos of Afghanistan, ${ }^{10}$ Rupert Murdoch's pledge of patriotism, ${ }^{11}$ embedded reporters self-censorship of images from Iraq, ${ }^{12}$ and the holding of Guantanamo prisoners without access to legal counsel. ${ }^{13}$ The author claims that "truth" in news reporting can only be found in public radio and television broadcasting. ${ }^{14}$

Additionally, the author blames the media itself for mediocre reporting of foreign events. He points to the closing of international branch offices of American news organizations over the last several years, indicating this led to a decline in international news reporting. More importantly, he argues, this has created a focus on sensationalistic reporting and a lesser acknowledgment, understanding, and appreciation of world cultures and political events. ${ }^{15}$ The author points out that, as a result, releases from the State Department, White House, and Pentagon ("Golden Triangle") are sometimes the only authorities considered. ${ }^{16}$ Moreover, he argues that a lack of understanding leaves a reporter in foreign territory relying solely on what has been made available by the country. An insightful quoted passage from an Egyptian reporter displays the frustration foreigners have with American media when reporters visit a country. The Egyptian reporter describes what he terms "the American Express Tour," whereby all American reporters visit and interview the same people at the same places in a short period of time before returning as "experts on the Middle East." 17 The author also includes another passage taken from a

7. Cole, supra note 1 , at 5-15.

8. Id. at 19.

9. Id. at 10 .

10. Id. at 11 .

11. Id. at 10.

12. Id. at 11-13.

13. Cole, supra note 1 , at 11-13.

14. Id. at 21 .

15. Id. at 15-21.

16. Id. at 9 .

17. Id. at 16 . 
Pakistani article, which pokes fun at American CNN correspondents but reveals that American news organizations appear to lack legitimacy in foreign countries because of a clear knowledge gap. ${ }^{18}$

While the author of this chapter makes valid points about the limitations of U.S. journalism and provides interesting supporting facts and data, in the end his efforts are somewhat undermined by the expressive belittling language and lack of impartial analysis. This highly critical and cynical chapter leaves the reader asking whether American journalism has any redeeming qualities. However, there is certainly no arguing the author's clear leftist-leaning personal views on current events.

\section{MALAYSIA ${ }^{19}$}

The author of this chapter describes Malaysia as a technologically advanced country with an advanced media network and a strict, powerful government. ${ }^{20}$ He points out that although Malaysia does not currently encounter terrorism on a large scale, its geographical location makes the country a key to militant operations in the Southeast Asian region, necessitating the country's political involvement in regional conflict. ${ }^{21}$ The author considers the primary terrorist coalition in Malaysia to be the Kumpulan Militan Malaysia ("KMM"). This group maintains connections with al Qaeda and shares membership and the ideology of creating a regional pan-Islamic state with the terrorist group Jemaah Islamiyah ("JI"). ${ }^{22}$ These two organizations remain on the U.S. list of foreign terrorist organizations, although the Malaysian government categorizes the KMM as an "extremist" group."

The author explains how the existence of these groups and the potential volatility of being geographically located among several other countries with rooted militant activity cause the Malaysian government to assert strong influence over the operation of the media networks. He notes that the government often takes advantage of their high esteem and access to the media to perpetuate state views and control reports critical of the

18. Id. at 16 .

19. This chapter was written by Benjamin Cole, co-author of The New Face of Terrorism. He also obtained a Ph.D. in International Relations from Southampton University.

20. Cole, supra note 1, at 23-24.

21. Id. at 23. Malaysia is essentially the geographic center between Thailand, Cambodia, Vietnam, and China to the North, the Philippines to the East, and Indonesia to the South and West.

22. See Council on Foreign Relations, Backgrounder-Jemaah Islamiyah, http://www. cfr.org/publication/8948/jemaah_islamiyah.html (last visited Feb. 25, 2007).

23. Cole, supra note 1 , at 23,25 . The author indicates that terrorism in Malaysia is defined as "killing of innocent civilians" with mitigating circumstances. 
government's four main policies. ${ }^{24}$ These policies emphasize challenging the objectives of militants, ${ }^{25}$ government protection of Muslim rights against militant groups and groups that fund them, ${ }^{26}$ opposing violence as the means to solving Islamic problems, ${ }^{27}$ and maintaining unity within the Muslim world and Malaysia. ${ }^{28}$ The administration uses the media to report government success in preserving national security and to disseminate its counterterrorism policies. $^{29}$ As a gatekeeper of news reporting, the government requires media outlets to obtain permits and regularly censors programming material. $^{30}$

The Malaysian population is familiar with the KMM, although the group does not actively publicize or attempt to access Malaysian media. ${ }^{31}$ Therefore, the author points out that reports of domestic KMM activities, ideologies, and violence are infrequent, although the government does allow reporting of member arrests and detentions. KMM and other militant activities are considered a regional and national issue and not associated with the global "War on Terror.", Alternatively, Malaysian media diligently reports on the activities of terrorist organizations and groups supporting a link between US foreign policy and oppression of Muslims. ${ }^{33}$ As such, the media frequently reports on JI and al Qaeda activities, including released messages from Osama bin Laden. ${ }^{34}$ They also report on activities of the nonviolent and less extreme Islamist political party, PAS, which also supports an "Islamic" state and the link between the U.S. and Muslim violence. ${ }^{35}$

As a result of the strong hand of government, the author explains that Malaysians are not left with access to objective reporting or thoughtful analysis of world politics. Regional illegal print publications do exist, but circulation is obviously limited and these publications are dangerous to maintain. ${ }^{36}$ Likewise, the Internet has provided an alternative news source for Malaysians, but the government requires service providers to hold a

24. Id. at 24 .

25. Id. at 35 .

26. Id.

27. Id. at 36 .

28. Id.

29. Cole, supra note 1 , at 37 .

30. Id. at 24 .

31. Id. at $25-26$.

32. Id. at 30 .

33. Id. at 28 . The bias is also anti-Western, including negative reporting regarding the motives of Russia, Israel, and Australia. Id.

34. Cole, supra note 1 , at 26-27.

35. Id. at 3.

36. Id. at 25 . 
license and has recently taken a more active role in censoring Islamic extremist Web sites. ${ }^{37}$

\section{INDONESIA ${ }^{38}$}

The author of this chapter focuses on the struggle that Indonesia faces as it attempts to modemize a country that is geographically divided and culturally and religiously diverse. ${ }^{39}$ He states that Indonesia is the largest Muslim nation and explains that due to its mix of faiths and varying levels of sophistication, the status of individual rights and political stability have ridden a rollercoaster ride over the years. Following its gain of independence in 1945, the country adopted a modern constitution stressing "pancasila" or the principles of one supreme God, humanitarianism, nationalism and unity, democracy, and social justice. ${ }^{40}$ But under the Suharto regime, it gave way to old habits of secrecy, military power, and cultural division. ${ }^{41}$ The author describes a "media boom" in 1999 whereby Indonesia opened its doors to media, and foreign programming flooded print, television, radio, film, and satellite with new images and ideas that the Indonesian population could not resist. ${ }^{42}$ This also created economic opportunity, enticing Indonesian business elites to invest in the new and emerging outlets and hope was held out for a free press. ${ }^{43}$ However, not surprisingly, press freedom makes the political elite nervous about foreign relations and criticism of the government. ${ }^{44}$

Currently, the Indonesian government supports the renewed regional political ideology committed to controlling domestic and regional militant organizations. ${ }^{45}$ The overriding fear of security among the Southeast nations drives the desire to keep a close watch on the media and what is released to the general public. ${ }^{46}$ Indonesia's specific concern is regional separatist movements and religious Muslim-Christian conflicts. ${ }^{47}$ The author shows that this renewed devotion to security issues has led to

37. Id. at $25-26$.

38. This chapter is written by Jonathan Woodier, the Director of Regional and Corporate Affairs for Citibank Asia Pacific.

39. Cole, supra note 1 , at 47.

40. Id.

41. Id. at $46-48$.

42. Id. at $43-45$.

43. Id. at 53 .

44. Id. at 56. This includes criticism from foreign press as well as domestic press. Prior to the 2004 election, Sydney Jones, an American researcher working for International Crisis Group, was expelled from the country in a presumed effort to silence criticism. Id. at 57.

45. Cole, supra note 1 , at $41-43$. This also includes anti-U.S. sentiment associated with U.S. actions in Afghanistan and Iraq.

46. Id. at 44-45.

47. Id. 
increasing power for political elites. ${ }^{48}$ Shortly after the "media boom," the government quickly reverted to pressuring the media by pursuing libel cases, revoking licenses, instituting media ownership rules against cross ownership and foreign ownership, and establishing a censorship board. ${ }^{49}$ Additionally, the military continues to take a role in monitoring safety, which includes asserting power over the media. ${ }^{50}$ The author explains that this is troubling, because due to its decreasing legitimacy and lack of sufficient funding, it has become a corrupt organization known to engage in illegal and brutal activities. ${ }^{51}$ As a result, the media is not freely accessible to all. Journalists are often restricted from accessing conflicted portions of the country and face dangerous pressure from both the military and the rebels. ${ }^{52}$

The author points out, however, that a glimmer of hope exists in the widespread use and advancement of the Internet and satellite technology. The Internet became accessible to the masses in the 1990s and went unchecked by the government. ${ }^{53}$ It played an important democratic role in the 2004 election, exposing candidates and information and even providing a certain amount of economic opportunity. ${ }^{54}$ Moreover, the political elite still find it increasingly difficult to police. ${ }^{55^{\circ}}$

\section{PHILIPPINES ${ }^{56}$}

As with the other countries in this region, the author of this chapter identifies the Philippines as a nation caught between several subnational and regional conflicts due to its geographical location. The Communist Party of the Philippines ("CPP"), New Peoples Army ("NPA"), Moro Islamic Liberation Front ("MILF"), JI, and Abu Sayyaf Group ("ASG") ${ }^{57}$ all maintain significant strongholds in the country and influence over the media. ${ }^{58}$ The author points out that while the U.S., EU, and some portions of the Filipino media categorize these groups as terrorist organizations and part of the "War on Terror," portions of the Filipino media simply label

48. Id. at 52 .

49. Id. at $41-44$.

50. Id. at 49-51.

51. Cole, supra note 1 , at $48-49$.

52. Id. One such example is the effort of the government against the Free Aceh Movement ("FAM") rebels in Aceh. Id.

53. Id. at 54 .

54. Id.

55. Id. at 53-55.

56. The author of this chapter is Benjamin Cole.

57. The author notes this group is the most violent of the groups operating in the Philippines and the most closely identified with al Qaeda. Cole, supra note 1, at 72-75.

58. Id. at 61,65 . 
them as guerillas, separatist organizations, or rebels. ${ }^{59}$ The U.S. has identified the Philippines as a central component in the "War on Terror" and has fostered relationships with the Filipino government. As a result, U.S. views and policies are positively reported in the media. ${ }^{60}$

The author explains that the CPP-NPA organization uses its ties to exploit the government corruption and expose the group's ideologies. ${ }^{61}$ They tend to operate in rural areas of the country and maintain a Web site frequently updated with reports, ideologies, and propaganda. ${ }^{62}$ According to the author, this is done in an effort to reach urban Filipinos as well. The MILF also operates a Web site for similar reasons, but it is more secular in its appeal, avoiding Islamic terms and lacking reference to the group's ideology. ${ }^{63}$ Additionally, MILF uses the media to portray the group as peaceful separatists and to encourage reports of its involvement in the regional peace process. ${ }^{64}$ The author points out that the JI arm in the Philippines does not have nor does it seek direct access to the media. The government legitimizes JI ideology by releasing reports of the group's activities of its own accord. ${ }^{65}$ Finally, the author explains how the ASG operates a perplexing relationship with the media, sometimes seeking media attention to intimidate the public and at other times kidnapping and blackmailing journalists that try to report on ASG events. ${ }^{66}$ As a result, ASG's effort to influence the media and public opinion since $9 / 11$ is not taken seriously. ${ }^{67}$

Despite the dangerous nature of the politics in the Philippines, the author indicates Filipino media is still considered one of the most progressive in this region as it takes an active role in rejecting and challenging government attempts at censorship. ${ }^{68}$ However, he notes that the transition is ongoing and complicated. A drive for sensationalistic programming, a desire to keep operation costs low, and a lack of professional journalistic standards still results in misreporting and skewed reporting of significant domestic events. ${ }^{69}$ Additionally, attempts to provide alternative sources and balanced reports have resulted in backlash from the Muslim community who argue that the media fails to define terms
59. Id. at 65 .
60. Id. at 78-79.
61. Id. at 64 .
62. Id. at 64-67.
63. Cole, supra note 1 , at $67-71$.
64. Id.
65. Id. at 71-72.
66. Id. at $72-76$.
67. Id. at 75 .
68. Id. at 80-81.
69. Cole, supra note 1 , at 63,76 . 
and distinguish between "terrorism" and the Muslim community as a whole. ${ }^{70}$ The author points out that "terrorist" activity in the Philippines prior to 2004 included a broad range of activities, including guerilla fighters, bandits, kidnappers, arsonists, murderers, and other general criminal activity.

\section{INDIA ${ }^{72}$}

The author of this chapter focuses specifically on the influences of Hindutva politics in the prosperous Gujarat region of India. ${ }^{73}$ This area is of particular interest, he argues, due to the long-standing political and social conflicts between Hindus and Muslims. ${ }^{74}$ The Hindutva political players include organizations comprising the Sangh parivar whose collective goal is to revitalize Hindu social and religious traditions. ${ }^{75}$ Some of these organizations focus on political dominance, ${ }^{76}$ while others are more focused on religious goals. ${ }^{77}$ The Hindutva has acquired a strong political influence in Gujarat. ${ }^{78}$ The author focuses on coverage of a 2002 attack on members of the Sangh parivar to illustrate the role, influences, and changes in Indian journalistic reporting.

The chapter points out that India's media is unique because of the culturally dichotomous nature of the country. On the one hand, India is politically and technologically advanced, exhibiting strong influences from western economy, democracy, and culture. However, the majority of India remains a developing country with strong religious and conservative hierarchical systems and many very poor populations isolated from the ideologies and advancements of western life. ${ }^{79}$ The mainstream media reflects this makeup by supporting two types of press: English-language and non-English-language. ${ }^{80}$ Understandably, this often results in the expression of differing perspectives. Unfortunately, this diversity is not necessarily accessible to the majority of the population because most do not

70. Id. at $62-63$.

71. Id.

72. The author of this chapter is Prasun Sonwalkar, an Indian journalist and professor of media studies at the University of the West of England.

73. The Gujarat region borders the Arabian Sea to the West and Pakistan to the North.

74. Cole, supra note 1 , at 85 .

75. Id. at 84 .

76. For example, the Bharatiya Janata Party ("BJP”) and Vishwa Hindu Parishad ("VHP"). Id.

77. For example, the Kar sevaks, a group working to build a temple to a Hindu god symbolizing wrongs against Hindus. Id. at 85-86.

78. Id. at $85-87$.

79. Id. at 82-84.

80. Cole, supra note 1, at 84 . 
possess English-language skills. ${ }^{81}$ Moreover, journalism can be a dangerous profession in Gujarat. Critical reporting of government actions and ideologies, certain groups, or individual participants can result in the media outlet or the individual journalist being banned, losing accreditation, financially strangled, provided restricted access, and in some cases subjected to physical violence. ${ }^{82}$ The author points out, however, that as a very large democratic nation, there is hope that new media outlets, growing media use, and increasing economic and social development will encourage the Indian media to pursue an independent watchdog function. ${ }^{83}$

\section{XINJIANG ${ }^{84}$}

The author of this chapter makes a point to show that, although the large northwestern region of Xinjiang is politically controlled by China, its geographical proximity to countries like Pakistan, Afghanistan, Kazakhstan, and Kyrgyzstan gives the people, language, culture, and ideology of this region an identity much more akin to its Russian and Middle Eastern neighbors than to its mother country. ${ }^{85}$ The author explains that the people of the Xinjiang region are essentially a mix of Uyghurs and Han-Chinese. ${ }^{86}$ Uyghurs are Muslims with Turkic traditions that speak Uyghur, while Han-Chinese maintain cultural traditions stemming from both Buddhism and Daoism and speak Chinese. ${ }^{87}$ Conflict in this region arises domestically between underprivileged separatist-minded Uyghurs on the one hand, and the communist Han-Chinese government ("CCP") and the Xinjiang Production and Construction Corps ("XPCC") on the other. ${ }^{88}$ Additionally, violence sometimes arises domestically between poor Uyghurs and educated Uyghurs. The latter are viewed as untrustworthy since many also speak Chinese and live or work in close proximity to HanChinese. $^{89}$

81. Id. at $82-84$.

82. Id. at 88-96. The author points out that specifically identifying attackers and victims by religious association was a practice not previously engaged in or supported as part of the "journalistic code" in Gujarat. The 2002 attack seems to be the first time this was done. Id. at 88-89.

83. Id. at 97.

84. The author of this chapter is Michael Dillon, an author and lecturer in Modem Chinese History.

85. Cole, supra note 1 , at $98-100$.

86. Id. at 100. Han-Chinese were introduced to this region following China's annexation of this region.

87. Id. at 98, 101. However, many Han-Chinese are not religious.

88. Id. at 100-02. XPCC is an arm of the People's Liberation Army ("PLA") devoted to securing the border regions. Id.

89. Id. 
China also struggles internationally to control violence with its northern and western neighbors. The country relaxed its migration policies following the fall of communism in central Asia and the strained trade relations that resulted. ${ }^{90}$ However, China did not change any of its policies regarding economic development of the West or religious freedom. ${ }^{91}$ Instead, the government quickly became nervous of an uprising in separatist Islamic activity due to the cultural similarities between the Uyghur people of the Xinjiang region and Uyghurs of the neighboring regions. ${ }^{92}$ According to the author, the country acted quickly to flex its persuasive muscle and amassed the Shanghai Co-operation Organization to protect its borders against violence and the influx of any Islamic materials that arguably support separatist ideologies or goals, including firearms and any Islamic literature. ${ }^{93}$ Domestically this also includes the regulation of religious practices and places of worship, birth control, and exporting of Xinjiang resources. ${ }^{94}$ Following $9 / 11$, China designated Islamic separatists as terrorists, linking them to al Qaeda and declaring them part of the "War on Terror." ${ }^{.95}$ The author reviews several incidents attributed to separatist terrorism, including riots, stealing weapons and cash, bomb explosions, rallies and demonstrations, protests, strikes, robbing and looting, and surrounding government buildings. ${ }^{96}$

As a communist country, the Chinese government obviously controls all media outlets, and as such, there are no independent state, regional, or local media. ${ }^{97}$ As a result, the conflicts and separatist movements in Xinjiang are not well covered, and access to the region is often restricted from journalist entry. ${ }^{98}$ The coverage of separatism that does exist in newspapers and on television, the author says, is largely focused on convictions of separatist criminal activities, arrests of members, and warnings not to get involved. ${ }^{99}$ Likewise, government materials are not distributed outside of the country, so the foreign media does not have access to these materials or reliable information upon which to report. ${ }^{100}$

90. Cole, supra note 1 , at 104.

91. Id. at 105-06.

92. The author points out that China has struggled to maintain power over various Muslim separatist movements throughout history. As a result, the government considers these movements the primary and highest national security threat. Id. at 102.

93. Id. at 104-05. This organization is comprised of leaders from China, Russia, Kazakhstan, Kyrgyzstan, Uzbekistan, and Tajikistan. Pakistan was not permitted to join. Id.

94. Id. at 105-06.

95. Cole, supra note 1 , at 111.

96. Id. at $107-08$.

97. Id. at 114-15.

98. Id. at 114 .

99. Id.

100. Id. 
Although the Internet helps this problem somewhat, it is not reliable. Internet access is not widely available to individuals and remains strictly monitored. ${ }^{101}$ According to the author, the best source of alternative information about the Xinjiang conflict comes from illegal Uyghur publications passed carefully within the region.

\section{CONCLUSION}

The authors of this book provide unique insight into the types of terrorism and conflict afflicting Asia. It is made clear that Asian governments operate similarly, but with varying degrees of success and influence over the media. The authors make a strong point that regardless of the nation, regional suspicion of cultural diversity and separatist movements fuel the desire to keep a close watch on the media and any journalistic attempt to criticize methods of maintaining national security. The authors collectively argue that, for the most part, U.S. policy and the "War on Terror" has not been successful in reducing conflict or terrorism in Asia. In some cases, the authors seem to imply that it has sparked further conflict, especially among Islamic communities. Further, although somewhat more subtly, the authors suggest that U.S. policies since September 11, 2001 have stalled democratic progress in Asia, strengthening governmental power and justifying restrictions on individual and press freedoms.

101. Cole, supra note 1 , at 115.

102. Id. 